\title{
Facile one-step vulcanization of copper foil towards stable Li metal anode
}

\author{
Danqi He ${ }^{1}$, Yaqi Liao ${ }^{1}$, Zexiao Cheng ${ }^{1}$, Xiahan Sang ${ }^{2}$, Lixia Yuan ${ }^{1}$, Zhen Li $^{{ }^{*}}$ and Yunhui Huang ${ }^{{ }^{*}}$
}

\begin{abstract}
Lithium metal has been regarded as the ultimate anode for next-generation rechargeable batteries with high energy density. However, its high reactivity and dendrite growth seriously limit its commercial application, which can be well addressed by realizing uniform $\mathrm{Li}$ deposition. Here, we report a facile and scalable one-step vulcanization method to modify commercial $\mathrm{Cu}$ foil with lithophilic $\mathrm{Cu}_{2} \mathrm{~S}$. The in situ formed $\mathrm{Cu}_{2} \mathrm{~S}$ layer can not only promote the homogeneous deposition of Li via its lithophilic nature, but also benefit the formation of a stable solid-electrolyte interphase during initial activation. The $\mathrm{Cu}_{2} \mathrm{~S}$-modified $\mathrm{Cu}$ current collector realizes dendrite-free Li plating/stripping and thus exhibits stable cycling performance with a high Coulombic efficiency, even with a large capacity of $4 \mathrm{~mA} \mathrm{~h} \mathrm{~cm}$. A full-cell consisting of a $\mathrm{Cu}_{2} \mathrm{~S} / \mathrm{Cu}-\mathrm{Li}$ anode and a $\mathrm{LiFePO}_{4}$ cathode exhibits greatly improved cycling stability and enhanced Coulombic efficiency, demonstrating the effectiveness and practicability of the proposed $\mathrm{Cu}_{2} \mathrm{~S} / \mathrm{Cu}$ foil in the field of rechargeable $\mathrm{Li}$ metal batteries.
\end{abstract}

Keywords: lithium metal anode, current collector, lithophilic layer, copper sulfide, electrochemical performance

\section{INTRODUCTION}

Lithium-ion batteries (LIBs) have completely changed our lifestyle in recent decades. With the emergence of many new applications, current commercial LIBs can hardly meet the increasing demands of high energy density [15]. Lithium metal has been considered as one of the most promising anodes for next-generation batteries, due to its quite high theoretical specific capacity $\left(3860 \mathrm{~mA} \mathrm{~h}^{-1}\right)$ and extremely low redox potential $(-3.04 \mathrm{~V}$ vs. standard hydrogen electrode) [6-8]. However, the Li dendrite growth issue is a main challenge for Li metal anodes [911]. The deposition of $\mathrm{Li}^{+}$on the interface is usually faster than its diffusion, so the growth of Li tends to be dendritic form, which may puncture the separator, induce short circuits, and even cause severe thermal runaway. The relatively high Fermi energy and large exposed surface area of a $\mathrm{Li}$ dendrite also lead to serious reactions with the liquid electrolyte. The formation of unstable solid electrolyte interphase (SEI) on the anode surface and the continuous consumption of electrolyte may cause low Coulombic efficiency and poor cycle stability of the full-cells [12-14]. Accordingly, this series of problems generated by Li dendrite growth greatly limit the commercial application of $\mathrm{Li}$ metal anodes. In recent years, extensive efforts have been devoted to resolving or mitigating the Li dendrite issue: (1) constructing uniform and compact SEI by in situ and ex situ methods is an efficient way. For example, introducing various additives $\left(\mathrm{LiNO}_{3}\right.$, $\mathrm{Li}_{2} \mathrm{~S}_{6}, \mathrm{HF}, \mathrm{Cu}\left(\mathrm{CH}_{3} \mathrm{COO}\right)_{2}$, $\left.\mathrm{LiF}\right)$ or optimizing the solvents to react with $\mathrm{Li}$ metal can in situ form a stable SEI layer [15-17]. It is also practicable to ex situ fabricate artificial SEI layers, including organic, inorganic, and hybrid films [18-21]. Although some SEI could effectively protect the $\mathrm{Li}$ metal anode during the $\mathrm{Li}^{+}$plating and stripping processes, the mechanical ability of thin SEI films is not steady enough to endure high areal capacity and prolonged cycles. (2) Using solid state electrolytes, such as solid polymer electrolytes or ceramic electrolytes, can physically prevent the growth of Li dendrites [22,23]. However, the ionic conductivity of the solid electrolyte is still not comparable to that of the liquid electrolyte at room temperature, and the non-intimate contact between the solid electrolyte and the Li metal may result in large interfacial impedance. (3) Reducing local deposition current density through employing three-dimensional (3D) current collectors can successfully avoid Li dendrite growth [24-27]. The 3D current collectors have a large

\footnotetext{
${ }^{1}$ State Key Laboratory of Material Processing and Die and Mold Technology, School of Materials Science and Engineering, Huazhong University of Science and Technology, Wuhan 430074, China

${ }^{2}$ State Key Laboratory of Advanced Technology for Materials Synthesis and Processing, Wuhan University of Technology, Wuhan 430070, China

* Corresponding authors (emails: li_zhen@hust.edu.cn (Li Z); huangyh@hust.edu.cn (Huang Y))
} 
specific surface area to reduce local current density and hence improve the uniformity of Li-ion deposition. However, at the same time, such current collectors (with large surface area) may promote side reactions between the electrolyte and the Li metal, reducing the volumetric energy density of the electrode.

Copper $(\mathrm{Cu})$ foil is the most common anodic current collector. Modifying $\mathrm{Cu}$ foil can improve the stability of a Li metal anode $[28,29]$. One effective strategy is to optimize the surface structure of $\mathrm{Cu}$ foil. Guo's group [30] took advantage of a 3D structure and constructed a submicron skeleton on the surface of a $\mathrm{Cu}$ current collector to ameliorate the electrochemical deposition behavior of $\mathrm{Li}^{+}$ions. Other strategies include reducing the nucleation overpotential and inducing the uniform deposition of $\mathrm{Li}^{+}$through various modified layers on $\mathrm{Cu}$ foil, such as hexagonal boron nitride, polyacrylonitrile (including polyacrylonitrile with polar functional groups), reduced graphene oxide, $\mathrm{ZnO}, \mathrm{Si}$, and $\mathrm{Sn}$ $[13,31,32]$. These modified layers are usually synthesized by complicated methods, such as atomic layer deposition or chemical vapor deposition [28], which may not be easily scaled up for mass production. Thus, it is of great importance to explore and develop new routes for facile and low-cost fabrication of current collectors with lithiophilic surfaces.

Here, we develop a one-step method by simple vulcanization of $\mathrm{Cu}$ foil to in situ form a modified layer of $\mathrm{Cu}_{2} \mathrm{~S}$ (Fig. 1a). With the assistance of the $\mathrm{Cu}_{2} \mathrm{~S}$ lithophilic layer, the nucleation overpotential of $\mathrm{Li}$ is significantly lowered and, hence, the deposition of $\mathrm{Li}^{+}$ions becomes much more uniform and dense (Fig. 1c). As a result, the prepared $\mathrm{Cu}_{2} \mathrm{~S} / \mathrm{Cu}$ current collector promises stable cycling performance with a high Coulombic efficiency in Li metal cells. A full-cell with $\mathrm{Li} / \mathrm{Cu}_{2} \mathrm{~S} / \mathrm{Cu}$ anode and $\mathrm{LiFePO}_{4}$ cathode exhibits good cycling stability and enhanced Coulombic efficiency, demonstrating the effectiveness and practicability of the $\mathrm{Cu}_{2} \mathrm{~S} / \mathrm{Cu}$ foil for rechargeable $\mathrm{Li}$ metal batteries.

\section{EXPERIMENTAL SECTION}

The $\mathrm{Cu}_{2} \mathrm{~S} / \mathrm{Cu}$ current collector was fabricated by a onestep method. Specifically, commercial $\mathrm{Cu}$ foil and pure sulfur powder were sealed within a tube furnace, where the sulfur was located near the $\mathrm{Cu}$ foil in the direction of the gas, and then heated to $400^{\circ} \mathrm{C}$ for 10 min under $\mathrm{Ar}$ atmosphere. The $\mathrm{Cu}_{2} \mathrm{~S} / \mathrm{Cu}$ current collector was obtained after the temperature dropped back to room temperature.

The phase constituents were determined by X-ray diffraction (XRD, Bruker D8-Advance) using $\mathrm{Cu}$ Ka radiation. The morphologies of all electrodes were observed by field emission scanning electron microscopy (FESEM, FEI Quanta 650 FEG). The high angle annular dark-field (HAADF) images, atomic resolution HAADF images, elemental mappings, and electron energy loss spectroscopy (EELS) were carried out by a double spherical aberration corrected transmission electron microscope (TEM, Thermo Fisher Titan Themis G2 60-300), for

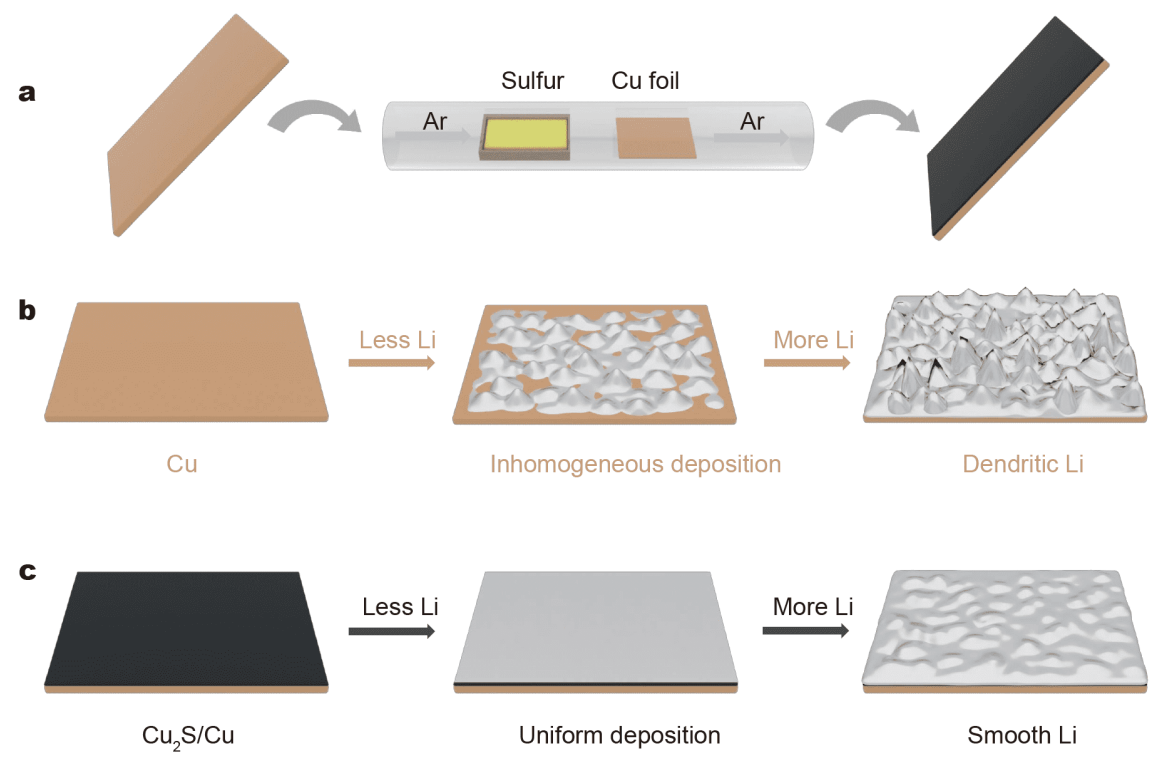

Figure 1 (a) Illustration of the in situ fabrication process of the $\mathrm{Cu}_{2} \mathrm{~S} / \mathrm{Cu}$ current collector. Schematics of different $\mathrm{Li}$ plating behaviors on (b) $\mathrm{Cu}$ and (c) $\mathrm{Cu}_{2} \mathrm{~S} / \mathrm{Cu}$ current collectors. 
which the sample was prepared by focused ion beam. To further analyze the SEI layer, X-ray photoelectron spectroscopy (XPS) of $\mathrm{S} 2 \mathrm{p}$ was recorded using a Thermo VG Multilab 2000 spectrometer.

All electrochemical properties were measured with standard CR2032 coin-type cells, all of which were assembled in the argon-filled glove box under the conditions of the oxygen with the water contents both below $0.5 \mathrm{ppm}$. The electrolyte was $1 \mathrm{~mol} \mathrm{~L}^{-1}$ LiTFSI in a mixture of 1,3-dioxolane (DOL) and dimethoxymethane (DME) $(v / v=1: 1)$ with $2 \mathrm{wt} \%$ of $\mathrm{LiNO}_{3}$. CR2032 coin cells were assembled with the $\mathrm{Cu}_{2} \mathrm{~S} / \mathrm{Cu}$ foil or bare $\mathrm{Cu}$ foil (both current collectors with $12 \mathrm{~mm}$ diameters) as the working electrode, the ether electrolyte, Celgard 2400 as the separator, and $\mathrm{Li}$ foil (with the same diameter of $12 \mathrm{~mm}$ ) as the counter-electrode. The cycling performance was measured on a Land Battery Measurement System (Land, China). To test the Coulombic efficiency, the cells were first cycled in the range of $0-1 \mathrm{~V}$ at $0.05 \mathrm{~mA}$ for three cycles for the formation of SEI. Then, different Li contents ( 1 and $4 \mathrm{~mA} \mathrm{~h} \mathrm{~cm}^{-2}$ ) were deposited onto the working electrodes at a current density of $1 \mathrm{~mA} \mathrm{~cm}$ and stripped away until the voltage reached $1 \mathrm{~V}$. Electrochemical impedance spectroscopy (EIS) was measured in the stripping state of cells after 50 cycles at a current density of $1 \mathrm{~mA} \mathrm{~cm}^{-2}$ with a capacity of $1 \mathrm{~mA} \mathrm{~h} \mathrm{~cm}^{-2}$. The voltage amplitude applied to the coin cells was $5 \mathrm{mV}$, with the frequency ranging from $100 \mathrm{kHz}$ to $1 \mathrm{~Hz}$. For the symmetric cell test, bare $\mathrm{Cu}$ foil or $\mathrm{Cu}_{2} \mathrm{~S} / \mathrm{Cu}$ foil was firstly deposited with $4 \mathrm{~mA} \mathrm{~h} \mathrm{~cm}^{-2}$ of $\mathrm{Li}$ in a half-cell, then taken out for assembling symmetric cells. The cycling performance of the symmetric cell was measured at a current density of $1 \mathrm{~mA} \mathrm{~cm}{ }^{-2}$ with a capacity of 1 or $4 \mathrm{~mA} \mathrm{~h} \mathrm{~cm}^{-2}$. For the full-cell test, the cathode electrode was made by mixing $80 \mathrm{wt} \%$ of $\mathrm{LiFePO}_{4}$ powder, $10 \mathrm{wt} \%$ of Super $\mathrm{P}$, and $10 \mathrm{wt} \%$ of polyvinylidene fluoride (PVDF) to form a homogeneous slurry. The slurry was spread onto $\mathrm{Al}$ foil and dried in vacuum at $120^{\circ} \mathrm{C}$ for $24 \mathrm{~h}$. The mass loading of $\mathrm{LiFePO}_{4}$ in the electrode was about $3 \mathrm{mg} \mathrm{cm}^{-2}$. To avoid any additional influence from the usage of the electrolyte, all cells for testing contained $50 \mu \mathrm{L}$ electrolyte.

\section{RESULTS AND DISCUSSION}

Lithophilic experiments of both $\mathrm{Cu}$ foil and $\mathrm{Cu}_{2} \mathrm{~S} / \mathrm{Cu}$ foil were simultaneously carried out (Fig. 2a). The yellow $\mathrm{Cu}$ foil and black-blue $\mathrm{Cu}_{2} \mathrm{~S} / \mathrm{Cu}$ foil (with the same diameter of $19 \mathrm{~mm}$ ) were placed in the stain steel cases, and pieces of $\mathrm{Li}$ foil (with diameter of $15 \mathrm{~mm}$ ) were placed onto the $\mathrm{Cu}$ foil and $\mathrm{Cu}_{2} \mathrm{~S} / \mathrm{Cu}$ foil, respectively. When heating to $300^{\circ} \mathrm{C}$, the sheet-shaped Li foil was quickly melted and turned into a sphere, due to the non-lithophilic ability of a

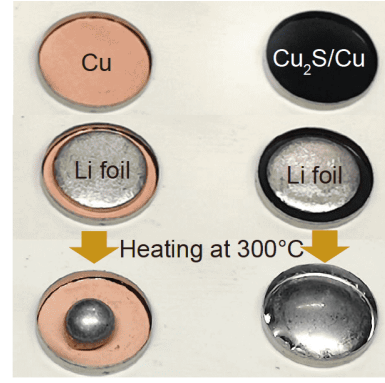

d

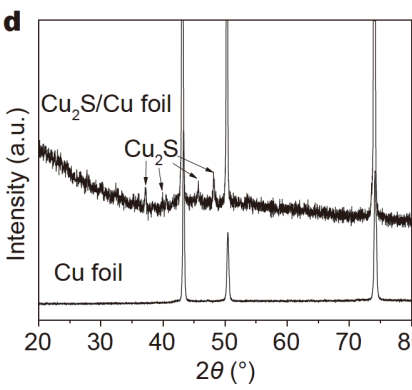

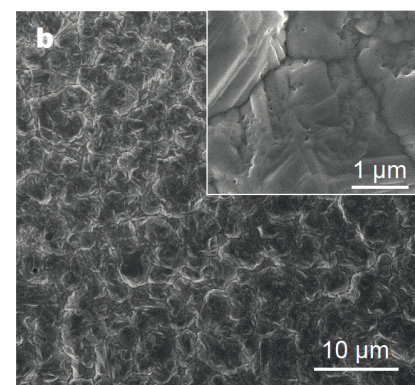
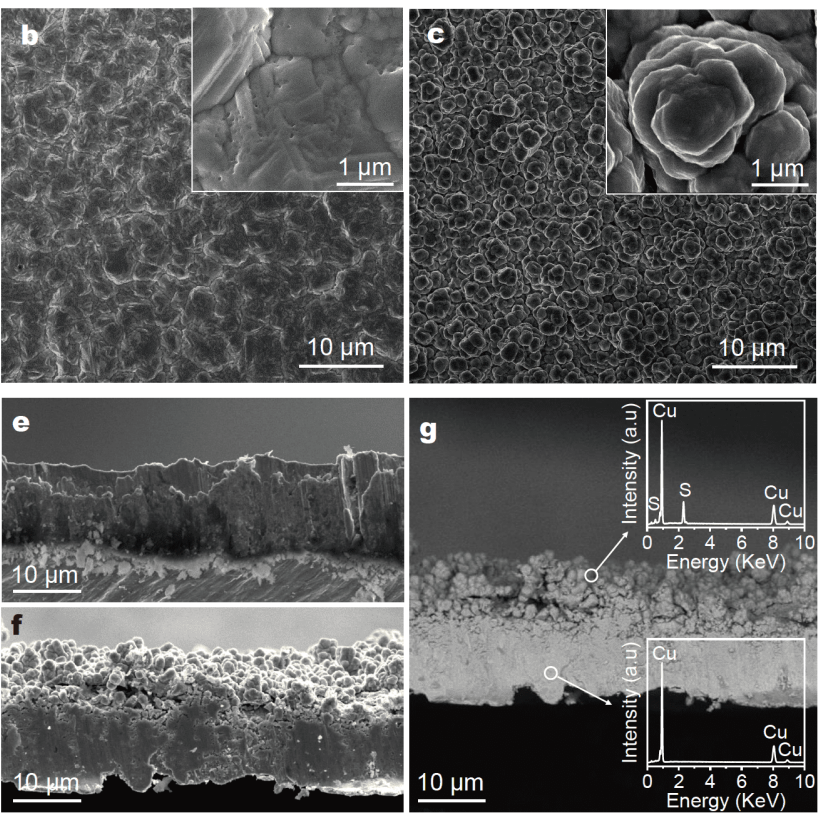

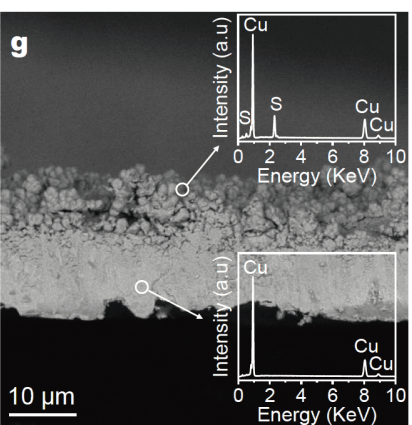

Figure 2 (a) The lithophilic experiment, revealing the lithophilic abilities of both the $\mathrm{Cu}$ foil and $\mathrm{Cu} \mathrm{S}_{2} \mathrm{~S} / \mathrm{Cu}$ foil. The surface morphologies of (b) $\mathrm{Cu}$

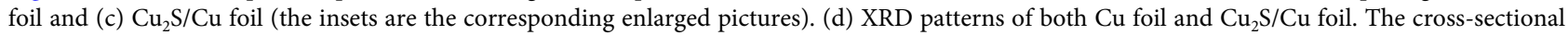
images of (e) $\mathrm{Cu}$ foil and (f) $\mathrm{Cu}_{2} \mathrm{~S} / \mathrm{Cu}$ foil. (g) The corresponding backscattering electron image of (f) (the insets are energy disperse spectroscopy patterns). 
$\mathrm{Cu}$. By contrast, the $\mathrm{Li}$ foil on $\mathrm{Cu}_{2} \mathrm{~S} / \mathrm{Cu}$ melted and spread out over the surface of the $\mathrm{Cu}_{2} \mathrm{~S} / \mathrm{Cu}$ foil under the same condition, indicating that $\mathrm{Cu}_{2} \mathrm{~S}$ has good lithophilic ability.

After vulcanization, the rough surface of the $\mathrm{Cu}$ foil (Fig. 2b) is covered by a layer of mushroom-like particles (Fig. 2c). XRD patterns show that some weak diffraction peaks of $\mathrm{Cu}_{2} \mathrm{~S}$ (JCPDS 84-207) appearing when the $\mathrm{Cu}$ foil gets through the vulcanization process (Fig. 2d), demonstrating that $\mathrm{Cu}_{2} \mathrm{~S}$ was successfully grown on the surface of the $\mathrm{Cu}$ foil. The thickness of the $\mathrm{Cu}$ foil is $14 \mu \mathrm{m}$ (Fig. 2e), while that of the $\mathrm{Cu}_{2} \mathrm{~S} / \mathrm{Cu}$ foil increases to around $19 \mu \mathrm{m}$ (Fig. 2f). From the corresponding backscattering electron image of the $\mathrm{Cu}_{2} \mathrm{~S} / \mathrm{Cu}$ foil (Fig. $2 \mathrm{~g}$ ), a layer of $\mathrm{Cu}_{2} \mathrm{~S}$ is in situ grown on the surface particle of the $\mathrm{Cu}$ foil. The results of energy disperse spectroscopy patterns (the insets in Fig. 2g) are also consistent with the corresponding XRD analysis.

With the help of double spherical aberration corrected TEM, we can further observe and confirm that the $\mathrm{Cu}_{2} \mathrm{~S}$ layer in situ grown on the $\mathrm{Cu}$ foil. Fig. 3a shows the HAADF image of the prepared $\mathrm{Cu}_{2} \mathrm{~S} / \mathrm{Cu}$ foil. Fig. $3 \mathrm{~b}$ and $c$ show the atomic resolution HAADF images of selected areas. The former image, along the [114] zone axis, matches with $\mathrm{CuO}$ (Fig. 3b), which results from the surface oxidation during sample preparation; the latter image, along the [110] and [010] zone axes, corresponds to $\mathrm{Cu}_{2} \mathrm{~S}$ (Fig. 3c), which is well consistent with the XRD pattern and energy disperse spectroscopy. These atomicresolution HAADF images also verify that the blue and magenta rectangular regions in Fig. $3 \mathrm{a}$ are the $\mathrm{Cu}$ substrate and the $\mathrm{Cu}_{2} \mathrm{~S}$ layer, respectively. Combined with the atomic resolution HAADF images, the elemental mappings of $\mathrm{Cu}$ and $\mathrm{S}$ for the whole region of Fig. 3a, shown

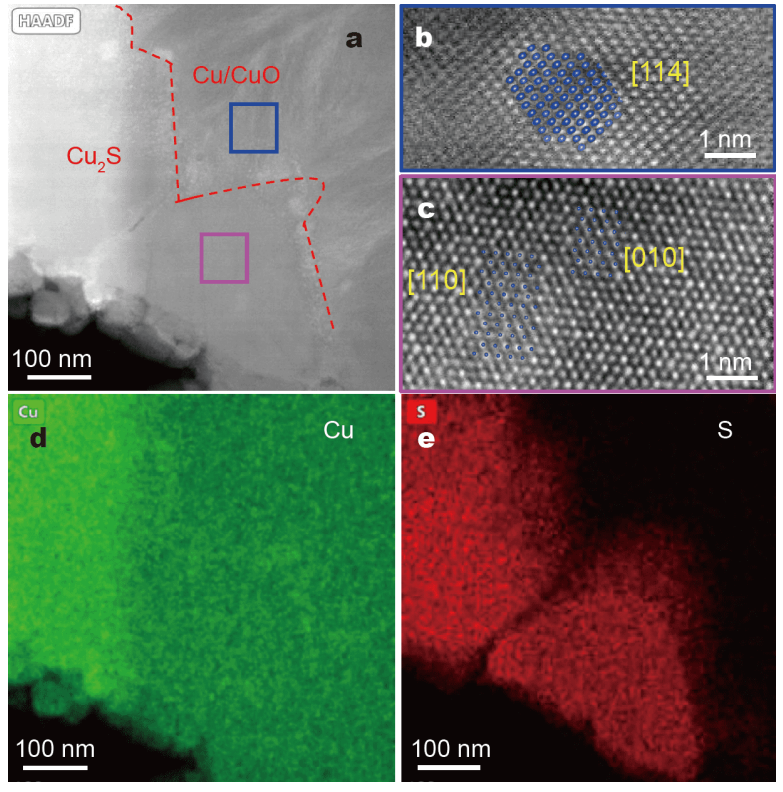

Figure 3 (a) HAADF image of $\mathrm{Cu}_{2} \mathrm{~S} / \mathrm{Cu}$ foil with clear phase interface. Atomic resolution HAADF images of (b) blue and (c) magenta rectangular regions in (a), respectively. Elemental mappings of (d) $\mathrm{Cu}$ and (e) $\mathrm{S}$ for the whole region in (a).

in Fig. $3 \mathrm{~d}$ and e, further confirm the phase interface between $\mathrm{Cu}_{2} \mathrm{~S}$ and $\mathrm{Cu}$ (see the red dotted line in Fig. 3a).

Fig. 4 displays the morphologies of the $\mathrm{Cu}$ foil and $\mathrm{Cu}_{2} \mathrm{~S} / \mathrm{Cu}$ foil after plating different Li contents. When using $\mathrm{Cu}$ foil as the current collector, it can be seen that the deposited Li has many cracks and a rough surface at a capacity of $1 \mathrm{~mA} \mathrm{~h} \mathrm{~cm}^{-2}$ (Fig. 4a). With increasing $\mathrm{Li}$ content, there are a lot of dendritic $\mathrm{Li}$, porous and dead lithium, due to non-uniform Li deposition (Fig. 4b-d). For the $\mathrm{Cu}_{2} \mathrm{~S} / \mathrm{Cu}$ foil, the surface morphology is much
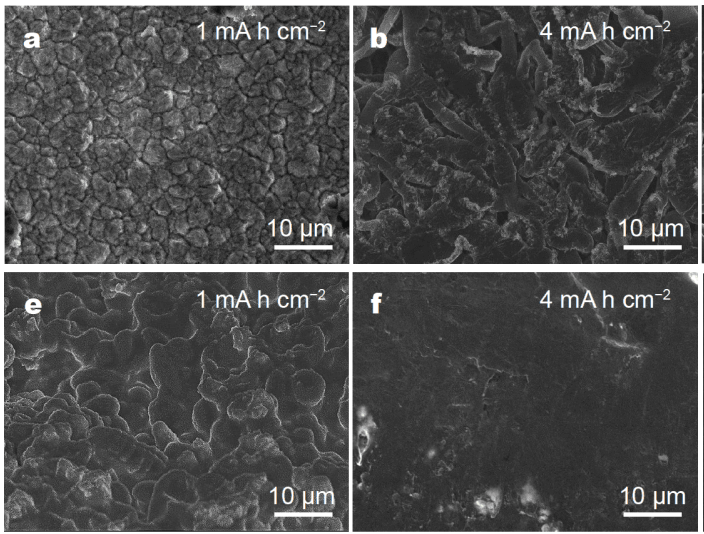
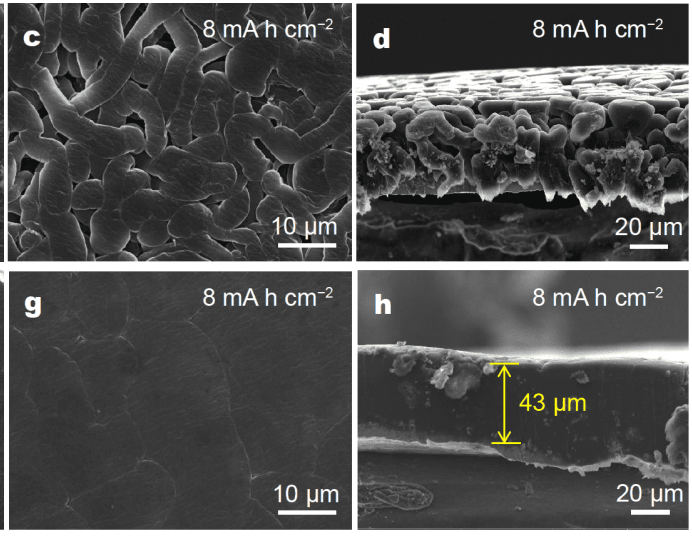

Figure 4 SEM images of the morphologies of Li deposition on $(\mathrm{a}-\mathrm{d}) \mathrm{Cu}$ and $(\mathrm{e}-\mathrm{h}) \mathrm{Cu}_{2} \mathrm{~S} / \mathrm{Cu}$ current collectors at a current density of $1 \mathrm{~mA} \mathrm{~cm}^{-2}$ with different capacities. 
flatter and denser (Fig. 4e-h). When plating a small amount of lithium $\left(1 \mathrm{~mA} \mathrm{~h} \mathrm{~cm}{ }^{-2}\right)$, lithium uniformly deposits with no cracking, due to the high lithophilic ability of $\mathrm{Cu}_{2} \mathrm{~S}$ (Fig. 4e). Even plating a capacity as high as $8 \mathrm{~mA} \mathrm{~h} \mathrm{~cm}{ }^{-2}$, the surface is still very smooth and no porous or dendritic Li appears (Fig. 4g). From the crosssectional image (Fig. 4h), we can see that, after plating at $8 \mathrm{~mA} \mathrm{~h} \mathrm{~cm}{ }^{-2}$, the thickness of the deposited lithium on the $\mathrm{Cu}_{2} \mathrm{~S} / \mathrm{Cu}$ foil is about $43 \mu \mathrm{m}$, which approaches that on $\mathrm{Li}$ foil $(40 \mu \mathrm{m})$, further indicating that $\mathrm{Cu}_{2} \mathrm{~S}$ can induce Li depositing and lead to extremely dense deposited lithium with no dead lithium or dendrite. Therefore, the $\mathrm{Cu}_{2} \mathrm{~S} / \mathrm{Cu}$ current collector enables the longer lifespan of a cell, even at a high total capacity.

The SEI layer is a vital factor for $\mathrm{Li}$ anode protection. Fig. $5 \mathrm{a}$ clearly shows the morphology of the $\mathrm{Cu}_{2} \mathrm{~S} / \mathrm{Cu}$ current collector after five depositing/stripping cycles. It can be seen that there is an intact SEI layer on the surface of the collector. To confirm the composition of the SEI layer, XRD test was carried out for both $\mathrm{Cu}$ and $\mathrm{Cu}_{2} \mathrm{~S} / \mathrm{Cu}$ current collectors after five cycles at Li totally stripped status (Fig. 5b). The diffraction peak of $\mathrm{Li}_{2} \mathrm{~S}$ only appears in the $\mathrm{Cu}_{2} \mathrm{~S} / \mathrm{Cu}$ foil. Combining with XPS spectra of $\mathrm{S} 2 \mathrm{p}$ (Fig. 5c), except for the peaks of Li salt and the oxidized part, it is ensured that $\mathrm{Li}_{2} \mathrm{~S}$ and $\mathrm{Li}_{2} \mathrm{~S}_{2}$ coexist in the outermost layer of the $\mathrm{Cu}_{2} \mathrm{~S} / \mathrm{Cu}$ foil. To further analyze the SEI layer formed on the surface of $\mathrm{Cu}_{2} \mathrm{~S}$, focused ion beam technology was employed to cut the $\mathrm{Cu}_{2} \mathrm{~S} / \mathrm{Cu}$ cur- rent collector after five depositing/stripping cycles for cross-sectional HAADF image (Fig. 5d). Fig. 5e shows the EELS of Li in the red rectangular area in Fig. 5d. It can be observed that there is rich Li distribution near the surface of the $\mathrm{Cu}_{2} \mathrm{~S} / \mathrm{Cu}$ foil, while there is almost no $\mathrm{Li}$ appearing near the $\mathrm{Cu}$ substrate region. This reveals that the SEI only formed on the surface of $\mathrm{Cu}_{2} \mathrm{~S}$, so $\mathrm{Cu}_{2} \mathrm{~S}$ has the benefit of forming a compact SEI layer, which can be also verified in the discharge profile at the first cycle (Fig. 5d). The discharge capacity of $\mathrm{Cu}$ foil is nearly zero, due to no reaction occurring between the $\mathrm{Cu}$ and $\mathrm{Li}$. By contrast, a clear voltage plateau appeared in the $\mathrm{Cu}_{2} \mathrm{~S} / \mathrm{Cu}$ foil, demonstrating that the surface of $\mathrm{Cu}_{2} \mathrm{~S}$ can firstly react with the $\mathrm{Li}$ before Li plating. This phenomenon may explain why the SEI contain $\mathrm{Li}_{2} \mathrm{~S}$ and $\mathrm{Li}_{2} \mathrm{~S}_{2}$ [33].

For heterogeneous nucleation of $\mathrm{Li}$, an energy barrier must be overcome, which is usually evaluated by the value of the nucleation overpotential determined by the difference between the voltage dip and the ultimate fat-part of the voltage plateau. Fig. $6 \mathrm{a}$ displays the voltage profiles of the $\mathrm{Li}$ plating on both $\mathrm{Cu}$ and $\mathrm{Cu}_{2} \mathrm{~S} / \mathrm{Cu}$ current collectors at the first cycle. Due to the non-lithophilic ability of $\mathrm{Cu}$ (Fig. 2g), the $\mathrm{Cu}$ foil exhibits a larger nucleation overpotential of $150 \mathrm{mV}$. By contrast, the $\mathrm{Cu}_{2} \mathrm{~S} / \mathrm{Cu}$ foil exhibits an extremely low nucleation overpotential of $23 \mathrm{mV}$, indicating that lithophilic $\mathrm{Cu}_{2} \mathrm{~S}$ can optimize the $\mathrm{Li}$ nucleation behavior and help to induce the uniform deposition of Li. After overcoming the energy barrier for

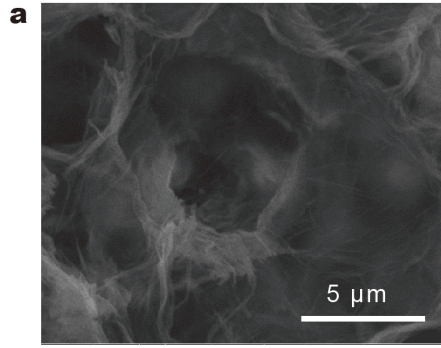

d

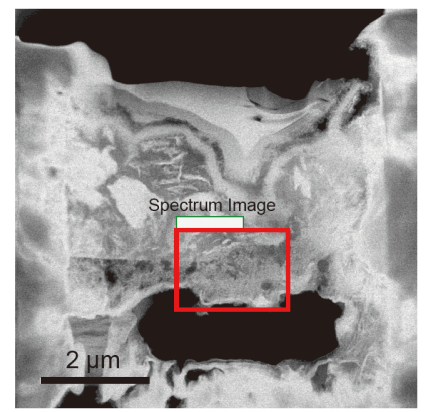

b
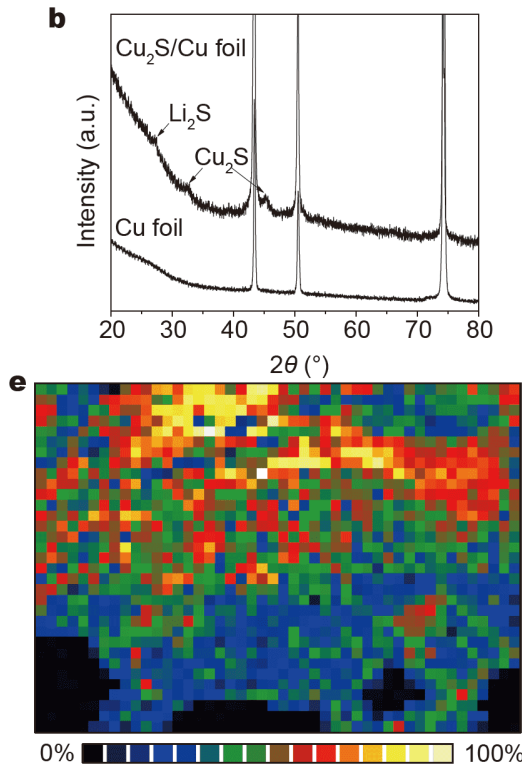
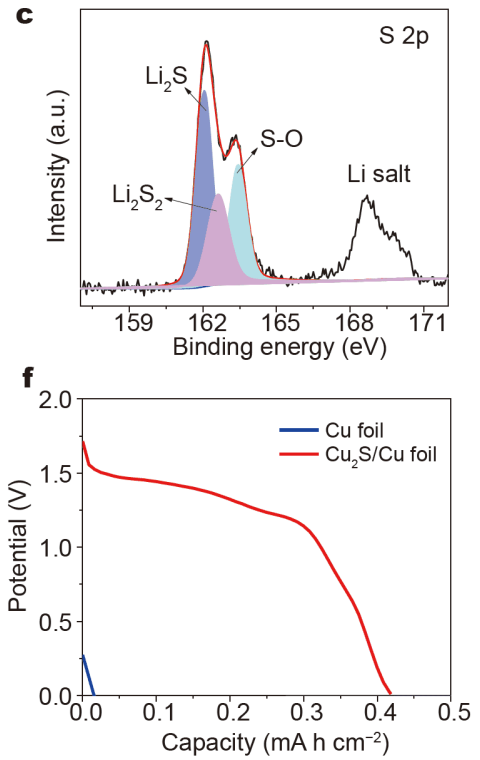

Figure 5 (a) The surface morphology, (c) XPS of S 2p, (d) HAADF image, and (e) EELS of elemental Li in the red rectangular region of (d) for the $\mathrm{Cu}_{2} \mathrm{~S} / \mathrm{Cu}$ current collector after five depositing/stripping cycles; (b) XRD patterns and (f) voltage profiles of both $\mathrm{Cu}$ and $\mathrm{Cu}{ }_{2} \mathrm{~S} / \mathrm{Cu}$ foil at the first discharge process. 

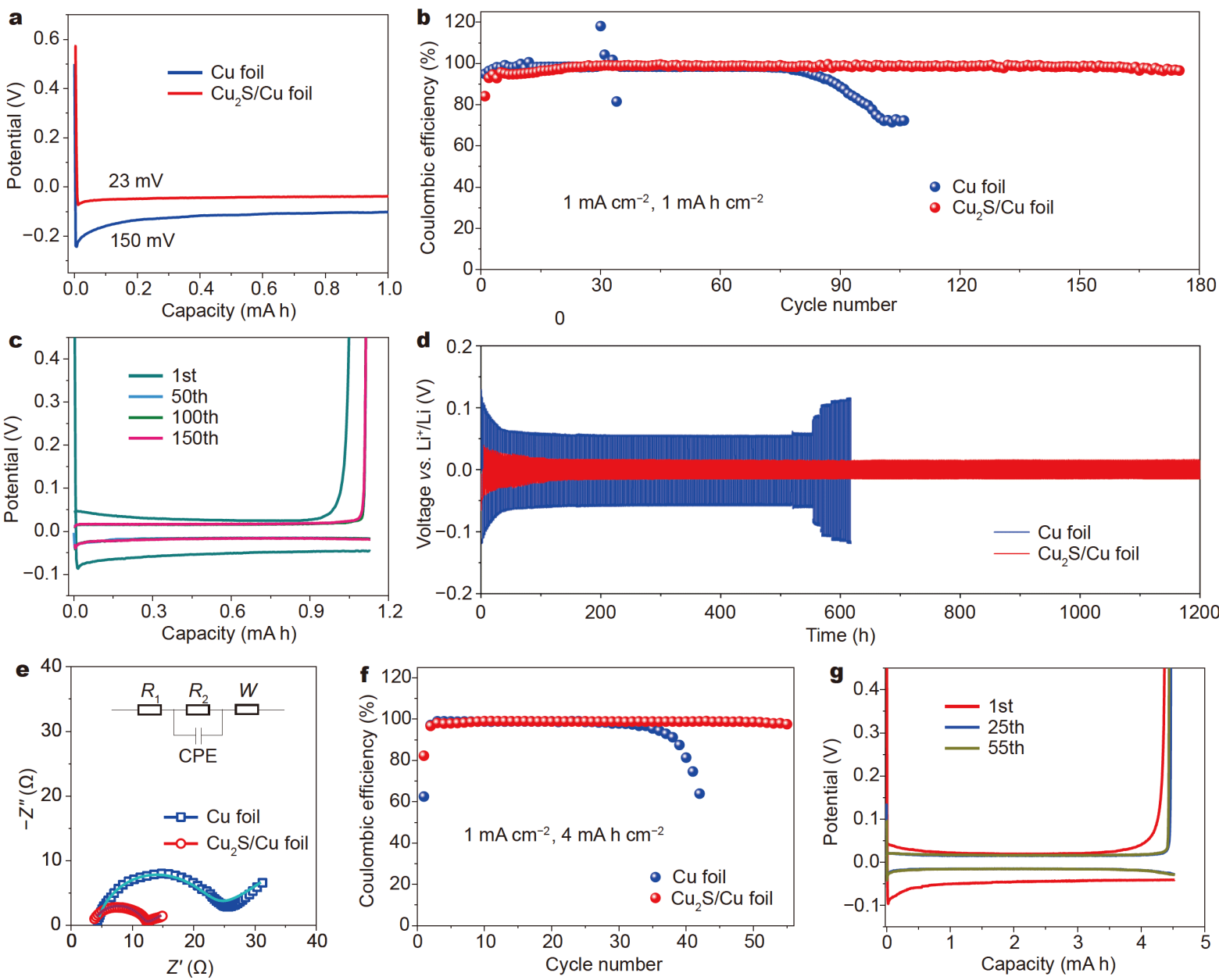

Figure 6 (a) Voltage profiles of Li nucleation on the $\mathrm{Cu}$ and $\mathrm{Cu}_{2} \mathrm{~S} / \mathrm{Cu}$ current collectors. Coulombic efficiencies of both $\mathrm{Cu}$ and $\mathrm{Cu}_{2} \mathrm{~S} / \mathrm{Cu}$ foils at a current density of $1 \mathrm{~mA} \mathrm{~cm}^{-2}$ with total capacities of (b) $1 \mathrm{~mA} \mathrm{~h} \mathrm{~cm}$ and (f) $4 \mathrm{~mA} \mathrm{~h} \mathrm{~cm}{ }^{-2}$. Voltage profiles of $\mathrm{Cu}_{2} \mathrm{~S} / \mathrm{Cu}^{-2}$ current collectors at a current density of $1 \mathrm{~mA} \mathrm{~cm}^{-2}$ with total capacities of (c) $1 \mathrm{~mA} \mathrm{~h} \mathrm{~cm}^{-2}$ and (g) $4 \mathrm{~mA} \mathrm{~h} \mathrm{~cm}^{-2}$. (d) Voltage-time profiles of symmetric Li $\| \mathrm{Cu}-\mathrm{Li}$ and $\mathrm{Li} \| \mathrm{Cu} 2 \mathrm{~S} / \mathrm{Cu}-$ Li cells at $1 \mathrm{~mA} \mathrm{~cm}^{-2}$ with a total capacity of $1 \mathrm{~mA} \mathrm{~h} \mathrm{~cm}^{-2}$. (e) EIS of $\mathrm{Cu}$ and $\mathrm{Cu}_{2} \mathrm{~S} / \mathrm{Cu}$ foils after 50 cycles.

heterogeneous nucleation of $\mathrm{Li}$, high Coulombic efficiency in every cycle and good cycle stability are essential for the cells. Fig. $6 \mathrm{~b}$ compares the Coulombic efficiency at a current density of $1 \mathrm{~mA} \mathrm{~cm}^{-2}$ with a total capacity of $1 \mathrm{~mA} \mathrm{~h} \mathrm{~cm}^{-2}$. It can be seen that the Coulombic efficiency of commercial $\mathrm{Cu}$ foil significantly drops to $70 \%$ after only 100 cycles, which can be ascribed to the increased dendritic $\mathrm{Li}$ and dead $\mathrm{Li}$ induced by the non-uniform lithium deposition during the continuous plating and stripping processes. In contrast, with the protection of the compact SEI layer formed in the initial voltage drop process, the Coulombic efficiency of the $\mathrm{Li} \| \mathrm{Cu}_{2} \mathrm{~S} / \mathrm{Cu}$ cell maintains much more stable over 180 cycles. Specifically, except for the first cycle, the charge/discharge curves of the $\mathrm{Cu}_{2} \mathrm{~S} / \mathrm{Cu}$ foil show no change, even after $150 \mathrm{Li}$ plating/stripping cycles (Fig. 6c).
Fig. 6d shows the voltage-time profiles of symmetric $\mathrm{Li} \| \mathrm{Cu}-\mathrm{Li}$ and $\mathrm{Li} \| \mathrm{Cu}_{2} \mathrm{~S} / \mathrm{Cu}-\mathrm{Li}$ cells at a current density of $1 \mathrm{~mA} \mathrm{~cm}^{-2}$ with a total capacity of $1 \mathrm{~mA} \mathrm{~h} \mathrm{~cm}^{-2}$. The polarization of the symmetric $\mathrm{Li} \| \mathrm{Cu}-\mathrm{Li}$ cell obviously increases after $500 \mathrm{~h}$, whereas the symmetric $\mathrm{Li} \| \mathrm{Cu}_{2} \mathrm{~S} / \mathrm{Cu}$ Li has excellent stability up to $1200 \mathrm{~h}$. In addition, the latter exhibits a much lower overpotential than the former during the prolonged cycling process. EIS profiles of both $\mathrm{Cu}$ and $\mathrm{Cu}_{2} \mathrm{~S} / \mathrm{Cu}$ foils after 50 cycles at $1 \mathrm{~mA} \mathrm{~cm}^{-2}$ are shown in Fig. 6e; the insets are their equivalent circuit curves. By simulating the impedance, the internal resistance $\left(R_{1}\right)$ of $\mathrm{Cu}_{2} \mathrm{~S} / \mathrm{Cu}$ foil after 50 cycles is $3.36 \Omega$, lower than that of $\mathrm{Cu}$ foil $(4.25 \Omega)$, which is mainly attributed to the more uniform $\mathrm{Li}$ position. Meanwhile, the interface resistance $\left(R_{2}\right)$ for $\mathrm{Cu}_{2} \mathrm{~S} / \mathrm{Cu}$ foil is $8.48 \Omega$, only half of that for $\mathrm{Cu}$ foil $(17.67 \Omega)$, which results from 

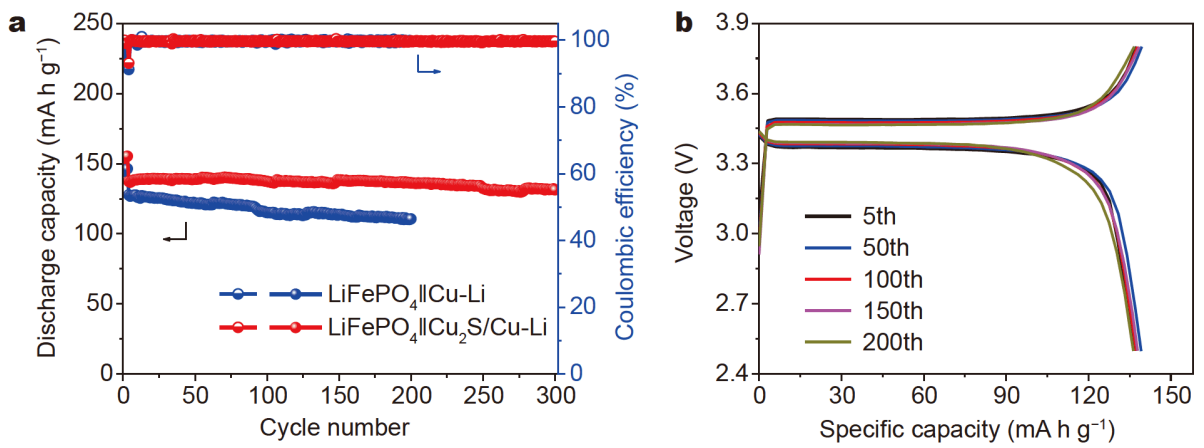

Figure 7 (a) Cycling performance of full-cells consisting of a $\mathrm{Cu}-\mathrm{Li}$ or $\mathrm{Cu}_{2} \mathrm{~S} / \mathrm{Cu}-\mathrm{Li}$ anode and a $\mathrm{LiFePO}_{4}$ cathode at a rate of $1 \mathrm{C}$. (b) Typical voltage profiles of the full-cell with $\mathrm{Cu}_{2} \mathrm{~S} / \mathrm{Cu}$ anode and $\mathrm{LiFePO}_{4}$ cathode at $1 \mathrm{C}$.

different amounts of dead Li and side reaction products in the two groups.

High areal capacity loading is crucial to realize high energy density. When increasing the areal capacity to $4 \mathrm{~mA} \mathrm{~h} \mathrm{~cm}{ }^{-2}$, the Coulombic efficiency of $\mathrm{Cu}$ foil quickly starts to drop after 30 cycles and decreases to about 70\% over 40 plating/stripping cycles. With $\mathrm{Cu}_{2} \mathrm{~S}$ modification, the Coulombic efficiency of the Li metal half cell maintains at about $98 \%$, indicating good reversibility and high utilization of Li during Li plating and stripping. Fig. $6 \mathrm{~g}$ shows the corresponding voltage profiles of $\mathrm{Cu}_{2} \mathrm{~S} / \mathrm{Cu}$ foil at different cycles, which indicates no change after 55 plating/stripping cycles.

To assess the potential of practical application for $\mathrm{Cu}_{2} \mathrm{~S} /$ $\mathrm{Cu}$ foil in Li metal batteries, two full-cells were assembled with $\mathrm{Li}$-plated $\mathrm{Cu}$ foil and $\mathrm{Cu}_{2} \mathrm{~S} / \mathrm{Cu}$ foil $\left(4 \mathrm{~mA} \mathrm{~h} \mathrm{~cm}^{-2}\right)$ as the anodes, coupled with a $\mathrm{LiFePO}_{4}$ cathode. The cycling performances of both full-cells were evaluated at a rate of $1 \mathrm{C}$ (Fig. 7a). The $\mathrm{LiFePO}_{4} \| \mathrm{Cu}_{2} \mathrm{~S} / \mathrm{Cu}$ - $\mathrm{Li}$ cell maintains a reversible capacity of $132 \mathrm{~mA} \mathrm{~h} \mathrm{~g}^{-1}$ with a stable average Coulombic efficiency of $99.6 \%$ and a capacity retention of $96 \%$ after 300 cycles, much better than that of $\mathrm{LiFePO}_{4} \|$ $\mathrm{Cu}-\mathrm{Li}$, with an average Coulombic efficiency of $99.4 \%$ and a capacity retention of $85 \%$ after 200 cycles. From the charge-discharge voltage profiles in Fig. $7 \mathrm{~b}$, we can see that the $\mathrm{LiFePO}_{4} \| \mathrm{Cu}_{2} \mathrm{~S} / \mathrm{Cu}$ - $\mathrm{Li}$ cell exhibits very stable voltage profiles, even at the 200th cycle, further demonstrating that the $\mathrm{Cu}_{2} \mathrm{~S}$ layer can effectively ensure the uniform deposition and stripping of Li to avoid dendrite growth.

\section{CONCLUSIONS}

We successfully modified commercial $\mathrm{Cu}$ foil by a simple one-step vulcanization method to form $\mathrm{Cu}_{2} \mathrm{~S}$ on the surface of a Cu-based current collector in situ. Due to the strong lithophilic ability of $\mathrm{Cu}_{2} \mathrm{~S}$, the nucleation over- potential of $\mathrm{Li}$ is greatly reduced to $23 \mathrm{mV}$, and the deposition of Li becomes uniform and compact even with a $\mathrm{Li}$ deposition content of up to $8 \mathrm{~mA} \mathrm{~h} \mathrm{~cm}{ }^{-2}$. As $\mathrm{Cu}_{2} \mathrm{~S}$ on $\mathrm{Cu}$ foil can help to form an SEI layer containing $\mathrm{Li}_{2} \mathrm{~S}$ and $\mathrm{Li}_{2} \mathrm{~S}_{2}$ in the initial activation process, the growth of dendritic $\mathrm{Li}$ is effectively retarded. Therefore, the $\mathrm{Cu}_{2} \mathrm{~S} / \mathrm{Cu}$ current collector exhibits very stable cycling performance with a high Coulombic efficiency of $97 \%$ for more than 180 cycles at a current density of $1 \mathrm{~mA} \mathrm{~cm}^{-2}$ with a total capacity of $1 \mathrm{~mA} \mathrm{~h} \mathrm{~cm}^{-2}$. Even when increasing the capacity to $4 \mathrm{~mA} \mathrm{~h} \mathrm{~cm}^{-2}$, the Coulombic efficiency can reach $98 \%$ for 60 cycles. The symmetric $\mathrm{Li} \| \mathrm{Cu}_{2} \mathrm{~S} / \mathrm{Cu}-\mathrm{Li}$ with low polarization also maintains excellent stability for $1200 \mathrm{~h}$. The full-cell with $\mathrm{Cu}_{2} \mathrm{~S} / \mathrm{Cu}$ foil as the anode and $\mathrm{LiFePO}_{4}$ as the cathode exhibited improved cycling stability and enhanced Coulombic efficiency, demonstrating that the $\mathrm{Cu}_{2} \mathrm{~S} / \mathrm{Cu}$ foil has excellent potential for practical application in Li metal batteries.

\section{Received 10 February 2020; accepted 21 March 2020;} published online 29 May 2020

1 Larcher D, Tarascon JM. Towards greener and more sustainable batteries for electrical energy storage. Nat Chem, 2015, 7: 19-29

2 Bruce PG, Scrosati B, Tarascon JM. Nanomaterials for rechargeable lithium batteries. Angew Chem Int Ed, 2008, 47: 2930-2946

3 Zhu Y, Cao T, Li Z, et al. Two-dimensional $\mathrm{SnO}_{2} /$ graphene heterostructures for highly reversible electrochemical lithium storage. Sci China Mater, 2018, 61: 1527-1535

4 Li W, Zeng L, Wu Y, et al. Nanostructured electrode materials for lithium-ion and sodium-ion batteries via electrospinning. Sci China Mater, 2016, 59: 287-321

5 Zhao Y, Ye Y, Wu F, et al. Anode interface engineering and architecture design for high-performance lithium-sulfur batteries. Adv Mater, 2019, 31: 1806532

$6 \mathrm{Xu} \mathrm{W}$, Wang J, Ding F, et al. Lithium metal anodes for rechargeable batteries. Energy Environ Sci, 2014, 7: 513-537

7 Fang C, Wang X, Meng YS. Key issues hindering a practical lithium-metal anode. Trends Chem, 2019, 1: 152-158 
8 Chen N, Dai Y, Xing Y, et al. Biomimetic ant-nest ionogel electrolyte boosts the performance of dendrite-free lithium batteries. Energy Environ Sci, 2017, 10: 1660-1667

9 Xiang J, Yang L, Yuan L, et al. Alkali-metal anodes: From lab to market. Joule, 2019, 3: 2334-2363

10 Wang J, Cui Y, Wang D. Design of hollow nanostructures for energy storage, conversion and production. Adv Mater, 2019, 31: 1801993

11 Cheng XB, Zhang R, Zhao CZ, et al. Toward safe lithium metal anode in rechargeable batteries: A review. Chem Rev, 2017, 117: 10403-10473

12 Tobishima S, Takei K, Sakurai Y, et al. Lithium ion cell safety. J Power Sources, 2000, 90: 188-195

13 Goriparti S, Miele E, De Angelis F, et al. Review on recent progress of nanostructured anode materials for Li-ion batteries. J Power Sources, 2014, 257: 421-443

14 Duan J, Tang X, Dai H, et al. Building safe lithium-ion batteries for electric vehicles: A review. Electrochem Energ Rev, 2020, 3: 1-42

15 Lang J, Long Y, Qu J, et al. One-pot solution coating of high quality LiF layer to stabilize Li metal anode. Energy Storage Mater, 2019, 16: 85-90

16 Liang X, Wen Z, Liu Y, et al. Improved cycling performances of lithium sulfur batteries with $\mathrm{LiNO}_{3}$-modified electrolyte. J Power Sources, 2011, 196: 9839-9843

17 Li W, Yao H, Yan K, et al. The synergetic effect of lithium polysulfide and lithium nitrate to prevent lithium dendrite growth. Nat Commun, 2015, 6: 7436

18 Liu QC, Xu JJ, Yuan S, et al. Artificial protection film on lithium metal anode toward long-cycle-life lithium-oxygen batteries. Adv Mater, 2015, 27: 5241-5247

19 Liu Y, Lin D, Yuen PY, et al. An artificial solid electrolyte interphase with high Li-ion conductivity, mechanical strength, and flexibility for stable lithium metal anodes. Adv Mater, 2017, 29: 1605531

20 Pathak R, Chen K, Gurung A, et al. Ultrathin bilayer of graphite/ $\mathrm{SiO}_{2}$ as solid interface for reviving Li metal anode. Adv Energy Mater, 2019, 9: 1901486

21 Luo J, Fang CC, Wu NL. High polarity poly(vinylidene difluoride) thin coating for dendrite-free and high-performance lithium metal anodes. Adv Energy Mater, 2018, 8: 1701482

22 Seino Y, Ota T, Takada K, et al. A sulphide lithium super ion conductor is superior to liquid ion conductors for use in rechargeable batteries. Energy Environ Sci, 2014, 7: 627-631

23 Tatsumisago M, Mizuno F, Hayashi A. All-solid-state lithium secondary batteries using sulfide-based glass-ceramic electrolytes. J Power Sources, 2006, 159: 193-199

24 Wu H, Zhang Y, Deng Y, et al. A lightweight carbon nanofiber- based 3D structured matrix with high nitrogen-doping level for lithium metal anodes. Sci China Mater, 2018, 62: 87-94

25 Duan H, Zhang J, Chen X, et al. Uniform nucleation of lithium in 3D current collectors via bromide intermediates for stable cycling lithium metal batteries. J Am Chem Soc, 2018, 140: 18051-18057

26 Lin D, Zhao J, Sun J, et al. Three-dimensional stable lithium metal anode with nanoscale lithium islands embedded in ionically conductive solid matrix. Proc Natl Acad Sci USA, 2017, 114: 46134618

27 Lyu Z, Lim GJH, Guo R, et al. 3D-printed electrodes for lithium metal batteries with high areal capacity and high-rate capability. Energy Storage Mater, 2020, 24: 336-342

28 Cho I, Gong S, Song D, et al. Mussel-inspired polydopaminetreated copper foil as a current collector for high-performance silicon anodes. Sci Rep, 2016, 6: 30945

29 Jiang J, Nie P, Ding B, et al. Effect of graphene modified Cu current collector on the performance of $\mathrm{Li}_{4} \mathrm{Ti}_{5} \mathrm{O}_{12}$ anode for lithium-ion batteries. ACS Appl Mater Interfaces, 2016, 8: 30926-30932

30 Yang CP, Yin YX, Zhang SF, et al. Accommodating lithium into 3D current collectors with a submicron skeleton towards long-life lithium metal anodes. Nat Commun, 2015, 6: 8058

31 Zhang SS, Fan X, Wang C. A tin-plated copper substrate for efficient cycling of lithium metal in an anode-free rechargeable lithium battery. Electrochim Acta, 2017, 258: 1201-1207

32 Deng D, Lee JY. Direct fabrication of double-rough chestnut-like multifunctional Sn@C composites on copper foil: Lotus effect and lithium ion storage properties. J Mater Chem, 2010, 20: 8045

33 Huang Z, Zhang C, Lv W, et al. Realizing stable lithium deposition by in situ grown $\mathrm{Cu}_{2} \mathrm{~S}$ nanowires inside commercial $\mathrm{Cu}$ foam for lithium metal anodes. J Mater Chem A, 2019, 7: 727-732

Acknowledgements This work was supported by the National Key R\&D Program of China (2018YFB0905400), the National Natural Science Foundation of China (51632001 and 51972131) and Chinese Postdoctoral Science Foundation. We thank the technical support from the Analytical and Testing Center of Huazhong University of Science and Technology (HUST) for material characterizations. We also thank Tang DG for help with XPS analysis from Key Laboratory of Catalytic Conversion and Energy Material Chemistry of Ministry of Education of South-Central University for Nationalities.

Author contributions $\mathrm{Li} Z \mathrm{Z}$ and $\mathrm{He} \mathrm{D}$ conceived the project. He D designed and engineered the samples. Liao Y, Cheng Z, and Sang X helped with the characterization. He D wrote the paper with support from Li Z and Huang Y. All authors contributed to the general discussion.

Conflict of interest The authors declare no competing interest. 


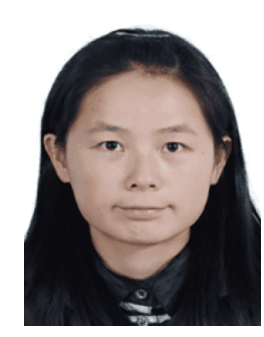

Danqi He is currently a post-doctoral fellow in the Department of Materials Science and Engineering, Huazhong University of Science and Technology (HUST), China. She received her $\mathrm{PhD}$ degree from the State Key Laboratory of Advanced Technology for Materials Synthesis and Processing of Wuhan University of Technology (WUT), China. Her research focuses on lithium-metal batteries and lithium-sulfur batteries.

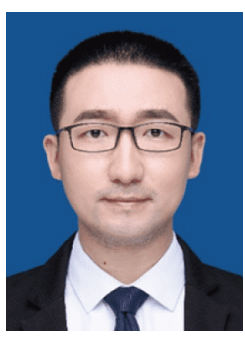

Zhen Li received his $\mathrm{PhD}$ degree from HUST in 2014. He worked as a R\&D engineer at Amperex Technology Limited (ATL) from 2009 to 2011 and worked as a postdoctoral researcher in $\mathrm{Na}$ nyang Technological University (NTU) from 2015 to 2018. In 2018, he became a professor of materials science in HUST. His research interests are lithium-ion batteries, lithium-sulfur batteries, and solid-state batteries.

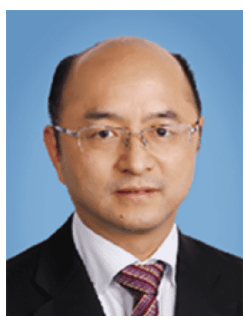

Yunhui Huang received his BS, MS, and $\mathrm{PhD}$ degrees from Peking University. From 2002 to 2004, he worked as an associate professor at Fudan University. He then worked with Prof. John B. Goodenough at the University of Texas at Austin for more than three years. In 2008, he became a chair professor of materials science at HUST. His research group works on rechargeable batteries and electrode materials.

\section{利用简单硫化处理的铜箔获取稳定的金属锂负极}

贺丹琪 ${ }^{1}$, 廖亚祺 ${ }^{1}$, 程泽晓 ${ }^{1}$, 桑夏晗 ${ }^{2}$, 袁利霞 ${ }^{1}$, 李真 ${ }^{{ }^{*}}$, 黄云辉 ${ }^{{ }^{*}}$

摘要 金属锂被认为是下一代高能量密度二次电池的终极形式. 但 是, 金属锂的高活性和枝晶生长严重限制了其商业化应用. 只有实 现锂离子的均匀沉积才能解决相关问题. 本研究通过对商业化铜 䇴进行简单的一步法硫化处理, 在其表面原位生成一层具有亲锂 性的 $\mathrm{Cu}_{2} \mathrm{~S}$ 修饰层. 该 $\mathrm{Cu}_{2} \mathrm{~S}$ 层不仅可以利用其亲锂性促进锂离子的 均匀沉积, 而且在初始活化过程中有利于形成稳定的固态电解质 界面. 在锂沉积/剥离循环过程中, 这种经过修饰的铜䇴集流体有 效抑制了锂枝晶生长, 即使在 $4 \mathrm{~mA} \mathrm{~h} \mathrm{~cm} \mathrm{~cm}^{-2}$ 的循环条件下, 也能够 展现出较高的库仑效率和稳定的循环性能. 将沉积金属锂后的 $\mathrm{Cu}_{2} \mathrm{~S} / \mathrm{Cu}-\mathrm{Li}$ 复合负极与 $\mathrm{LiFePO}_{4}$ 正极组装成全电池, 其循环稳定性 和库仑效率均大幅度提高, 表明该修饰后的铜筞在二次金属锂电 池领域具有良好的应用前景. 